\title{
Performance of hybrid solar-biomass dryer
}

\author{
M. K. Mishra ${ }^{1 *}$, K. R. Shrestha ${ }^{1^{*}}$, V. Sagar ${ }^{2}$, R. K. Amatya ${ }^{1}$ \\ ${ }^{1}$ Research Center for Applied Science and Technology (RECAST), Tribhuvan University, Kirtipur, Nepal, \\ ${ }^{2}$ B. N. M. University, Madhepura, Bihar, India.
}

\begin{abstract}
Drying of agriculture product is energy intensive and traditional open sun drying is associate with many problems. Use of solar dryer is one of the alternative options. However, it is problematic in rainy and cloudy days. In order to measure the efficiency of solar/biomass hybrid dryer was proposed. A solar/biomass hybrid dryer was fabricated in RECAST Lab. Wood blocks were used as fuel for the gasifier stove. Biomass burning gasifier stove was integrated with solar dryer as an auxiliary heat source through a heat exchanger. The hybrid system of biomass with solar dryer ensures to provide continuous heat when needed. Due to the intermittent nature of sun, especially in rainy or cloudy season, food materials being processed get spoiled. A hybrid solar/biomass drying system solve such problems. Experiments were conducted to test performance of hybrid solar dryers by drying chili and banana. During the load test, conducted for chili, $16 \mathrm{~kg}$ of ripen chili with initial moisture content $72.58 \%$ (w. b.) was dried to moisture content of $7.13 \%$ (w. b.) in 20 hours. The result indicated that drying of chili was faster, within 20 hours (2 days), in natural sunny weather, against 48 hours (5 days) in open sun drying during April, in Kathmandu. Overall efficiency of drying system was found to be $4.29 \%$.
\end{abstract}

Key words: Efficiency, hybrid solar-biomass dryer, heat transfer, moisture content

\section{Introduction}

The traditional method of crop drying practiced over the centuries throughout the world seems to be open sun drying, where diverse crops such as fruits, vegetables, cereals, grains, tobacco, etc. are spread on the ground and turned regularly until sufficiently dried. However, this creates many problems associated with open sun drying namely cloudiness and rain, infestation by insects and pests, high level of dust and atmospheric pollution and intrusion from rodent and animals. In addition to this, there is no control of drying process. Uncontrolled drying also results either over drying or under drying, resulting inferior quality of the product, which are harmful (Ahuja et al.,1987).

Drying of agricultural products is one of the processes which are very high energy intensive. One of the measures to reduce fossil energy refinement for drying agricultural products is through the use of solar dryer. Solar energy collected by flat plate solar collectors can be practical and economical method to dry agricultural products (Bala, 1997). The ongoing research on solar dryers proved that both natural and forced convection dryers perform better than open sun drying (Asper \& Shiun, 1975).

Although, various types of solar dryers have been developed in many countries over a period of time. The solar dryers can be classified according to their heating modes or the manner in which the heat derived from the solar radiation is utilized (Gnanaranjan., 1997).

${ }^{*}$ Corresponding author, email address: mishra 273@gmail.com
Although, solar dryers are technically feasible, their applications are still limited. In cloudy days, rainy season, cold winters and even at night, the temperature of the dryer gets down to ambient temperature, the heating and cooling of the dryer may affect the taste and the quality of the product. Moreover, it may influence the efficiency of the dryer. In the hybrid biomass fueled stove on solar dryer, the dependency on sun will be reduced, while food materials will be saved from being spoiled. The efficiency of the hybrid system will also be increased (Shrestha, 2000).

The gasifier stove-heat exchanger system is especially designed for the complement of the solar operated dryer. This paper evaluates the performance of hybrid solar/biomass dryer against solar dryer and open sun drying.

\section{Materials and Methods \\ Experimental Set Up \\ Design of the biomass fueled dryer}

The following four major components of the biomass fueled drying system were developed (Fig. 1).

- Biomass Gasifier

- Heat exchanger

- Drying chamber

- Temperature controller 
A gasifier stove design was selected as the heat source for the biomass- fueled drying system because it gives clean combustion. The gasifier stove (IGS-2) was fabricated at RECAST (Research Centre for Applied Science \& Technology) workshop as per the design of Asian Institute of Technology (AIT), Thailand. The gasifier stove consists of four main parts, i.e. fuel storage hopper, reaction chamber, primary air inlet and combustion chamber. Each part of the stove was independent and can be attached together by bolts and nuts.

Fuel Hopper was made of mild steel sheet and was located above the reaction chamber. The height of the hopper was $70 \mathrm{~cm}$ with an upper dimension of $30 \times 17 \mathrm{~cm}$ and a lower dimension of 17 $\mathrm{x} 17 \mathrm{~cm}$.

Reactor was considered as the heart of the stove where gas was produced. The dimension of the reaction chamber was $17 \mathrm{x} 17$ x $22 \mathrm{~cm}$. A mild steel door $(22 \mathrm{~cm}$ x $22 \mathrm{~cm})$ was provided at the front of ash pit for removing the accumulated ash. Primary air inlet was made of $2 \mathrm{~mm}$ thick mild steel sheet. A butterfly valve was placed inside the drying chamber for providing controlled amount of primary air supply.

The gas produced in the combined chamber was burned and flue gas was generated (Fig. 2). The outer dimension or the chamber was $20 \times 20 \mathrm{~cm}$, while the producer gas inlet has a cross- sectional area of $7 \times 12.5 \mathrm{~cm}$. A fire glass was installed at the top of the connector for observing the combustion flame (Mahandari, 1997).
A cross-section of heat exchanger was chosen with hot flue gas flowing inside the inner fin-duct, while the process air flowed through it within a shell box. The heat exchange unit was fixed at the bottom of the drying chamber.

From the calculation, the total heat transfer area required was estimated to be $2.88 \mathrm{~m}^{2}$. A rectangular shaped duct was chosen (Fig. 2). The designed duct was $120 \mathrm{~cm}$ in length, $70 \mathrm{~cm}$ in width and $5 \mathrm{~cm}$ in height having a total surface area of $1.8 \mathrm{~m}^{2}$. To improve the performance of the heat exchanger, 56 fins, each of $3 \mathrm{~cm}$ height were installed and they were arranged parallely at $4 \mathrm{~cm}$ spacing along the width of the duct to increase the heat transfer area. One end of the duct was connected to the gasifier stove and the other was connected to chimney.

Drying chamber of gasifier stove has four shelves inside, on which the materials to be dried can be placed. The dimensions of drying chamber were $100 \mathrm{~cm}$ in width, $120 \mathrm{~cm}$ in length and $220 \mathrm{~cm}$ in height (excluding the ventilator and chimney). There were four trays inside the chamber and the distance between two adjacent trays was $25 \mathrm{~cm}$. The first tray was placed $5 \mathrm{~cm}$ above the heat exchanger unit.

The maximum permissible temperature for fruits and vegetable drying was about $70^{\circ} \mathrm{C}$. A thermostat commonly used in car radiator cooling system (Fig. 3) was used for temperature control of the drying chamber.

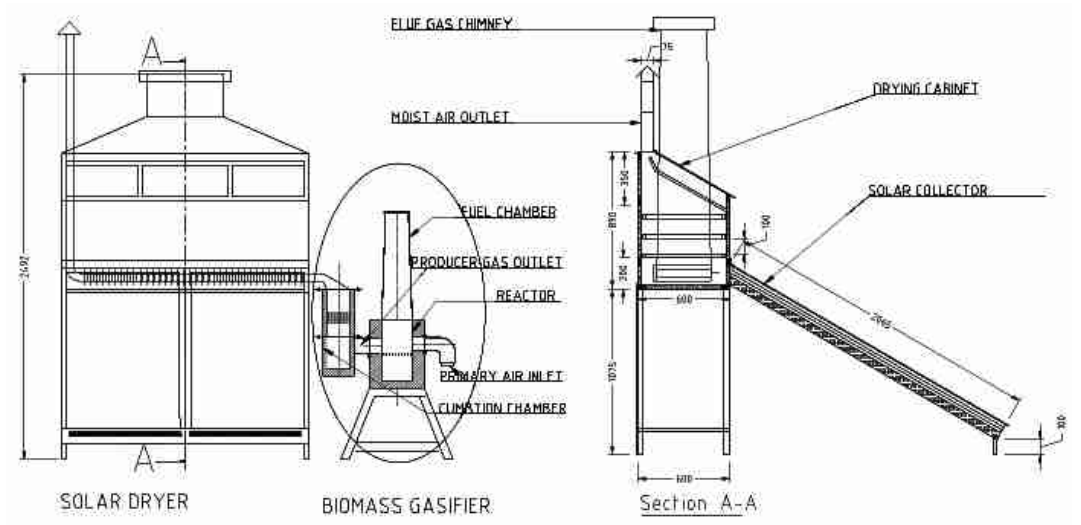

Figure 1 Diagrammatic sketch of hybrid solar-biomass dryer

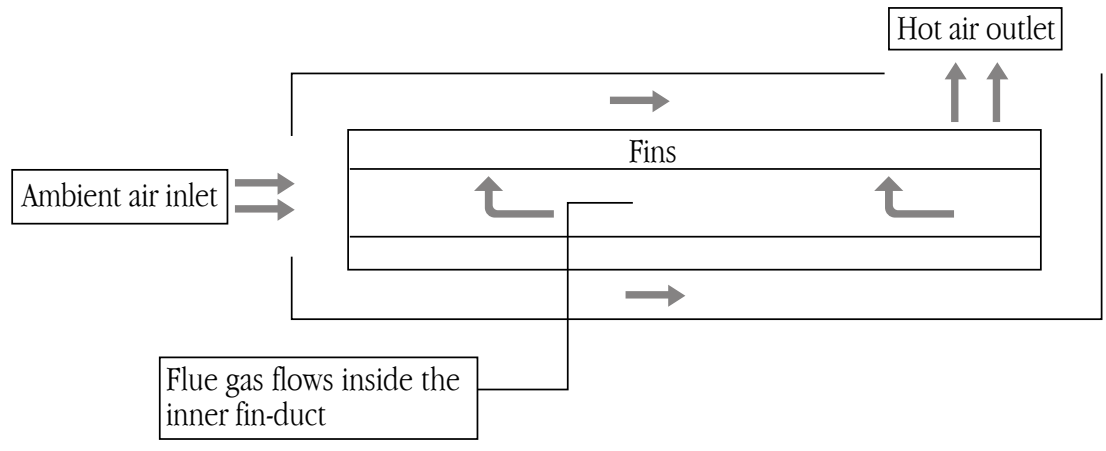

Figure 2 Heat exchanger and air flow pattern

\section{谣TU-CDES}




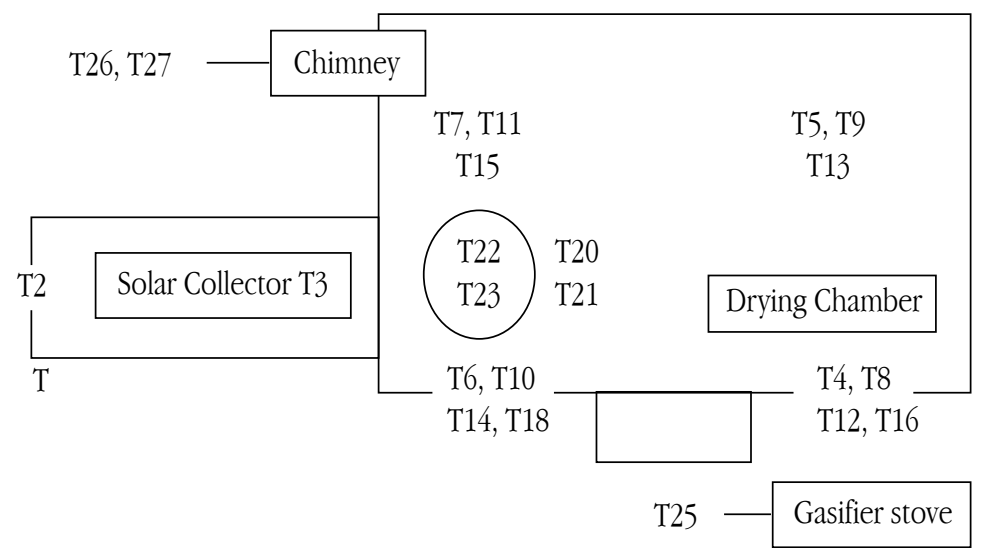

\begin{tabular}{|c|c|}
\hline T1 & $=$ Ambient temperature \\
\hline $\mathrm{T} 2$ & $=$ Dry bulb temperature at collector inlet \\
\hline 3 & $=$ Dry bulb temperature at collector outlet/heat exchanger inlet \\
\hline $4, \mathrm{~T} 5, \mathrm{~T} 6, \mathrm{~T} 7$ & $=$ Dry bulb temperature at the first tray \\
\hline $8, \mathrm{~T} 9, \mathrm{~T} 10, \mathrm{~T} 11$ & $=$ Dry bulb temperature at the second tray \\
\hline $12, \mathrm{~T} 13, \mathrm{~T} 14, \mathrm{~T} 1$ & $=$ Dry bulb temperature at the third tray. \\
\hline $16, \mathrm{~T} 17, \mathrm{~T} 18, \mathrm{~T}$ & $=$ Dry bulb temperature at the fourth tray \\
\hline$[20, \mathrm{~T} 21$ & $=$ Dry and wet bulb temperature at the middle of the drying chamber \\
\hline T22, T23 & $=$ Dry and wet bulb temperatures at drying chamber at outlet \\
\hline 24 & $=$ Dry bulb temperature at thermostat. \\
\hline & $=$ Dry bulb temperature the flue gas at heat exchanger inlet \\
\hline & $=$ Dry bulb temperature of the flue gas at heat exchanger outlet \\
\hline & $=$ Dry bulb temperature of the flue gas as end of chimney \\
\hline
\end{tabular}

Figure 3 Positions of thermocouples installed in the drying unit

\section{Raw material (fuel for gasifier stove)}

Wood chips were used as fuel of the gasifier stove. The wood chips were cut from 2-meter-long wood sticks of square section $(2 \mathrm{~cm}$ x $2 \mathrm{~cm}$ ) brought from a local shop.

The proximate analysis of the wood chips sample was done as per ASTM standards D3172-73. The higher heating value of the oven dried biomass sample was determined in a standard bomb calorimeter by the ASTM D2075-77 (Table 1).

\section{Products to be dried}

Banana and chili were selected for drying in this study as they were easily available in the local market. The fresh bananas and chilies were dried as whole fruits without any chemical pre treatment.

\section{Experimental procedure \\ Calibration}

Before starting the experimental procedure, some calibrations were needed. The aim of air flow rate calibration was to know the flow rate though the dryer during operating set-up. This was done by noting the readings of a hot- wire anemometer for known flow rate of air (as measured by a rotameter) supplied from outside.
The aim of thermocouple calibration was to obtain reliable temperature data from the thermocouples, used to measure the temperature. This was done by comparing the output of the thermocouple reading with a standard thermometer. They were placed in a water bath where a standard thermometer was also placed. The thermocouples were calibrated before positioning them in the dryer unit.

\section{Procedure}

The experimental study on the dryer was done under two options:

- Operate by using only the gasifier stove as heat source

- Operate by using both gasifier stove and solar energy as heat source (Hybrid system).

\section{No load test}

The preliminary experiments at no-load were conducted to observe the temperature that can be attained with any product being dried. Three cases were tested,

A. Operate the set up without control

B. Operate the set up with control: air gets out from wind ventilator and. 
C. Operate the set up with control: air gets out from chimney for case (B) and (C). The experiments were carried out to compare the variation of the temperatures inside the drying chamber and to find the best position of the thermostat inside the drying chamber. The efficiency of the drying system for no- load test was determined by following equation (Mastekbayeva, 1998)

$\left.\mathrm{n}_{\text {no-load }}=\left[\mathrm{m}_{\text {air }} \mathrm{x}_{\text {p,air }} \mathrm{x}\left(\mathrm{T}_{\text {out }}-\mathrm{T}_{\text {amb }}\right)\right] . / \mathrm{E}_{\text {input }}\right]$

$\mathrm{E}_{\text {input }}=\left[\mathrm{M}_{\mathrm{f}} \times \mathrm{H}_{\mathrm{f}}\right]$ for biomass - fueled dryer and

$\left.=\left[\mathrm{C}_{\mathrm{mf}} \times \mathrm{H}_{\mathrm{f}}\right)+\left(\mathrm{Ix} \mathrm{A}_{\mathrm{c}}\right)\right]$ for hybrid system.

Where,

$\mathrm{M}_{\text {air }}=$ mass flow rate of air $(\mathrm{kg} / \mathrm{s})$

$\mathrm{C}_{\mathrm{p} \text {,air }}=$ specific heat of process air $(\mathrm{kJ} / \mathrm{kg} / \mathrm{C})$

$\mathrm{T}_{\text {out }}=$ temperature of process air at drying chamber outlet $\left({ }^{\circ} \mathrm{C}\right)$

$\mathrm{T}_{\mathrm{amb}}=$ ambient temperature of $\operatorname{air}\left({ }^{\circ} \mathrm{C}\right)$

$\mathrm{M}_{\mathrm{f}} \quad=$ fuel feed rate $(\mathrm{kg} / \mathrm{s})$

$\mathrm{H}_{\mathrm{f}} \quad=$ calorific value of fuel $(\mathrm{kJ} / \mathrm{kg})$

$\mathrm{I} \quad=$ total solar radiation input $\left(\mathrm{kJ} / \mathrm{s}-\mathrm{m}^{2}\right)$

$\mathrm{A}_{\mathrm{C}} \quad=$ solar collector $\left(\mathrm{m}^{2}\right)$

The fuel to be used in the test was weighted and loaded into the biomass stove. Combustion chamber was warmed up about 10 minutes. Time was recorded since ignition of the stove unit until the fuel was burned completely. The temperatures at various points and air velocity were also recorded during the experiment (Fig. 3).
From Fig. 3, it can be seen that the temperature of the process air inside the drying chamber exceed $80^{\circ} \mathrm{C}$ (higher than the permissible temperature for drying fruits) was not used. With the control system, the process air can be reduced to about $70^{\circ} \mathrm{C}$.

During experiments in cases (b) and (c), the thermostat was placed $40 \mathrm{~cm}$ above the heat exchanger unit. To reduce the temperature of process air to the preferred level $\left(50-60^{\circ} \mathrm{C}\right)$ the thermostat was placed $25 \mathrm{~cm}$ above the heat exchanger unit for drying of banana and chili in load test.

\section{Fuel consumption air flow rate and efficiency of the drying system on no load test}

Wood chips consume in the gasifier stove and time elapses between appearance and extinction of flame in the combustion chamber were recorded. The rate of fuel combustion was obtained by dividing the total amount of fuel consumed by the time elapses (Table 2).

From the calorific value of wood chip, the efficiency of the system was calculated as follows.

$\mathrm{n}_{\text {no load }}=\left[\mathrm{m}_{\text {air }} \times \mathrm{Cp}\right.$, air x $\left.\left(\mathrm{T}_{\text {out }}-\mathrm{T}_{\text {in }}\right)\right] /\left[\mathrm{M}_{\mathrm{p}} \times \mathrm{H}_{\mathrm{p}}\right]$

Therefore, the efficiency of the biomass-fueled dryer in this case is,

$$
\begin{aligned}
\mathrm{n}_{\text {load }} & =0.0916 \\
& =9.16 \%
\end{aligned}
$$

\section{Load test}

The load tests were conducted on the dryer unit to evaluate its performance and to study the drying rate of the products. Drying experiments were carried out with banana and chilli.

Table 1 Proximate analysis and heating value of wood chip

\begin{tabular}{ccccccc}
\hline \multicolumn{2}{c}{ Heating value $[\mathrm{MJ} / \mathrm{kg}]$} & & \multicolumn{4}{c}{ Proximate analysis (\%) } \\
\cline { 1 - 2 } \cline { 5 - 6 } HHV $_{\mathrm{d}}$ & $\mathrm{LHVw}$ & & Moisture content & Volatile matter & Fixed carbon & Ash content \\
19.57 & 16.84 & & 7.37 & 74.85 & 16.30 & 1.48 \\
\hline
\end{tabular}

Table 2 Drying system on no-load test

\begin{tabular}{lccc}
\hline & Case A & Case B & Case C \\
\hline Fuel used $(\mathrm{kg})$ & 7 & 7 & 3 \\
Time elapses $(\mathrm{min})$ & 160 & 185 & 95 \\
Fuel consumption rate $(\mathrm{Kg} / \mathrm{hr}$.) & 2.62 & 2.27 & 1.89 \\
Airflow rate * $\left(\mathrm{m}^{3} / \mathrm{hr}\right.$.) & $98 / 77 / 64$ & $107 / 77 / 64$ & $60 / 45 / 36$ \\
Efficiency $(\%)$ & 9.16 & 7.89 & 5.96 \\
\hline
\end{tabular}

* Maximum/average/minimum values

\section{Results and Discussion Drying of banana}

The banana (about $23 \mathrm{~kg}$ ) for the experiment were bought from the local market. Sixteen Kilograms of peeled bananas were spread on the trays (Table 3).

The initial moisture content of the banana used in the test was 67.37\% on wet basis (wb) (Annex I, Fig. 4). The final weight and moisture content of the banana were measured to be $6.79 \mathrm{~kg}$ (Table 3) and 24.02\% (wb) (Annex I) respectively.

\section{部TU-CDES}


The natural sun drying on the peeled bananas was also conducted for comparison. The peeled bananas of 1.6 kilograms were exposed in the sun. The weight and moisture content of the bananas were measured to be $0.62 \mathrm{~kg}$ and $27.44 \%$ (wb) in the final day (data not shown).

\section{Drying time and efficiency of banana on biomass fueled dryer} In this experiment, the time duration for drying the bananas to the required final moisture content was about 18 hours for biomassfueled dryer and 66 hours for natural sun drying (Annex I).

In addition, it was seen that the time needed for drying banana placed on the second, third and fourth tray to about $27 \%$ moisture content on wet basis was 12 hours but the first tray needs 6 more hours for drying (Fig. 4).

From the experimental data, the drying efficiency in each day and the overall drying efficiencies were calculated (Table 3).

\section{Drying chili}

The ripe chilies $(18 \mathrm{~kg}$ ) used in the experiment were bought from local market. $16 \mathrm{~kg}$ of chili were spread on the trays and were loaded into the drying chamber. The initial moisture content was used in the test was 71.23\% on wet basis (Annex II). The final weight and moisture content of the chili were measured $4.54 \mathrm{~kg}$ and $7.07 \%(\mathrm{wb})$ respectively. It can be seen that the required final moisture content of chili was reached in the biomass-fueled dryer within 22 hours (Fig. 6), while it required 48 hrs. (5 days) for open sun drying (Tanit, 1999).

Two kilograms of the chilies were dried in the natural sun for comparison. Weight and moisture content of the dried chili were measured to be $0.69 \mathrm{~kg}$ and $7.82 \%$ (w. b) in the final day.

\section{Drying time and efficiency of chilies on biomass fueled dryer}

The results show that the drying efficiency was highest on the first day at which moisture content of the chili was still very high (Table 4, Fig. 5). As the moisture content decreased, the efficiency of the system also reduces especially on the last day of drying. The average fuel consumption rate, air flow rate and the overall efficiency were $2.05 \mathrm{~kg} / \mathrm{hr} .81 .25 \mathrm{~m}^{3} / \mathrm{hr}$. and $3.67 \%$ respectively (Table 4).

\section{Performance of hybrid biomass/solar dryer operation of chili drying}

After finishing the tests on the dryers using heat from biomass combustion alone for drying, the setup was moved outside and expose to the sun for the study on hybrid operation.

Table 3 Banana drying on biomass fueled dryer (in shed)

\begin{tabular}{lcccccc}
\hline & Day I & Day 2 & Day 3 & Day 4 & Day 5 & Overall \\
\hline Initial weight of banana $(\mathrm{kg})$ & 16.0 & 13.48 & 11.24 & 9.21 & 6.99 & 16.0 \\
Final weight of banana $(\mathrm{kg})$ & 13.48 & 11.24 & 9.21 & 6.99 & 6.79 & 6.79 \\
water evaporated(kg) & 2.52 & 2.24 & 2.03 & 2.22 & 0.20 & 9.21 \\
Energy needed to evaporate $(\mathrm{kJ})$ & 6,300 & 5,600 & 5,075 & 5,550 & 500 & 23,025 \\
Fuel used $(\mathrm{kg})$ & 7.0 & 7.0 & 7.0 & 12.0 & 7 & 40 \\
Time elapsed (min) & 170 & 196 & 195 & 324 & 184 & 1087 \\
Fuel consumption rate $(\mathrm{kg} / \mathrm{hr}$ ) & 2.47 & 2.14 & 2.15 & 2.11 & 2.28 & 2.21 \\
Air flow rate * $\left(\mathrm{m}^{3} / \mathrm{hr}\right.$.) & $117 / 85 / 64$ & $125 / 77 / 57$ & $137 / 80 / 64$ & $198 / 78 / 57$ & $148 / 82 / 57$ & 8.4 \\
Energy supplied to the system $(\mathrm{MJ})$ & 117.88 & 117.88 & 117.88 & 202.08 & 117.88 & 673.63 \\
System efficiency $(\%)$ & 5.34 & 4.75 & 4.31 & 2.75 & 0.42 & 3.42 \\
\hline
\end{tabular}

* maximum/average/minimum values

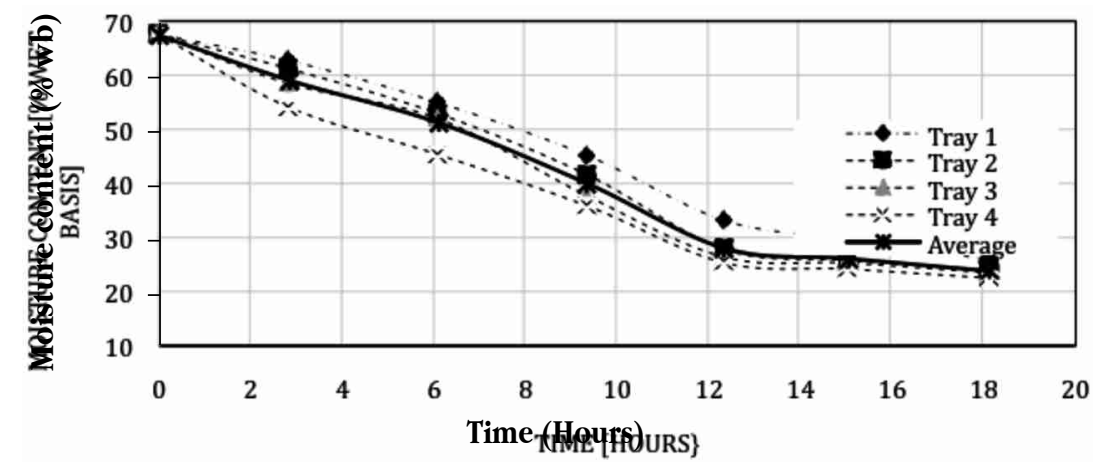

Figure 4 Drying profile of banana on biomass fueled dryer (in shade) 


\section{No-load test}

As in operation with biomass energy alone, the test on no-load conditions was carried out for three cases (Table 2).

\section{Temperature profile}

The temperature at various points of the system was also measured every two minutes. The temperature profiles of process air and flue gas during experimentation of various cases are shown in Fig. 6.

For hybrid operation, the process air first heats at the solar collector. As seen in the Fig. 6, the air temperature was increased from about $30^{\circ} \mathrm{C}$ to about $40-60^{\circ} \mathrm{C}$ at the collector outlet. So the temperature of process air getting into heat exchanger unit for hybrid system was higher than the temperature of process air in case of using biomass fuel alone.

\section{Fuel consumption, air flow rate and efficiency of the drying system}

The wood chips consumed, time elapsed, average air flow rate and calculated results were shown in (Table 5).

\section{Load test (chili drying)}

For hybrid operation, the load test was carried out only with the chili. As in the test using biomass fuel alone as the heat source, sixteen kilograms of the chilies spread on the trays were loaded into the drying chamber.

The initial moisture content of the chili was $72.58 \%$ on wet basis. The final weight and moisture content of the chili (after drying) were measured to be $4.66 \mathrm{~kg}$ and $7.13 \%$ (w. b) respectively.

For this test, the setup was operated continuously (about ten hours per day) so the final required moisture content can be reached within two days (Fig. 6), while it requires 48 hrs. (5 days) for open sun drying.

\section{Drying efficiency}

The results of chili drying for hybrid solar/biomass powered operation of the dryer show that the drying efficiency was the highest on the first day when moisture content of the chili was still very high (Table 6). When moisture content was decreased during drying, the efficiency of the system was also reduced. The overall efficiency for hybrid operation was measured to be $4.29 \%$ (Table 6).

Table 4 Drying chili on biomass fueled dryer

\begin{tabular}{lccccc}
\hline & Day I & Day 2 & Day 3 & Day 4 & Over all \\
\hline Initial weight of chili $(\mathrm{kg})$ & 16.0 & 12.49 & 8.02 & 4.81 & 16.0 \\
Final weight of chili $(\mathrm{kg})$ & 12.49 & 8.02 & 4.81 & 4.64 & 4.64 \\
Water evaporated $(\mathrm{kg})$ & 3.51 & 4.47 & 3.21 & 0.17 & 11.36 \\
Fuel used $(\mathrm{kg})$ & 7.0 & 14.0 & 18.0 & 7 & 46 \\
Time elapsed (min) & 185 & 406 & 555 & 200 & 1,346 \\
Fuel consumption rate (kg/hr.) & 2.27 & 2.14 & 1.94 & 2.10 & 2.05 \\
Energy Supplied to the system (MJ) & 117.88 & 235.76 & 306.12 & 117.88 & 774.64 \\
Air flow rate x (M3/hr.) & $148 / 93 / 72$ & $117 / 79 / 47$ & $89 / 71 / 49$ & $137 / 82 / 48$ & 81.25 \\
System efficiency \% & 7.44 & 4.74 & 2.65 & 0.36 & 3.67 \\
\hline
\end{tabular}

* Maximum/average/minimum values

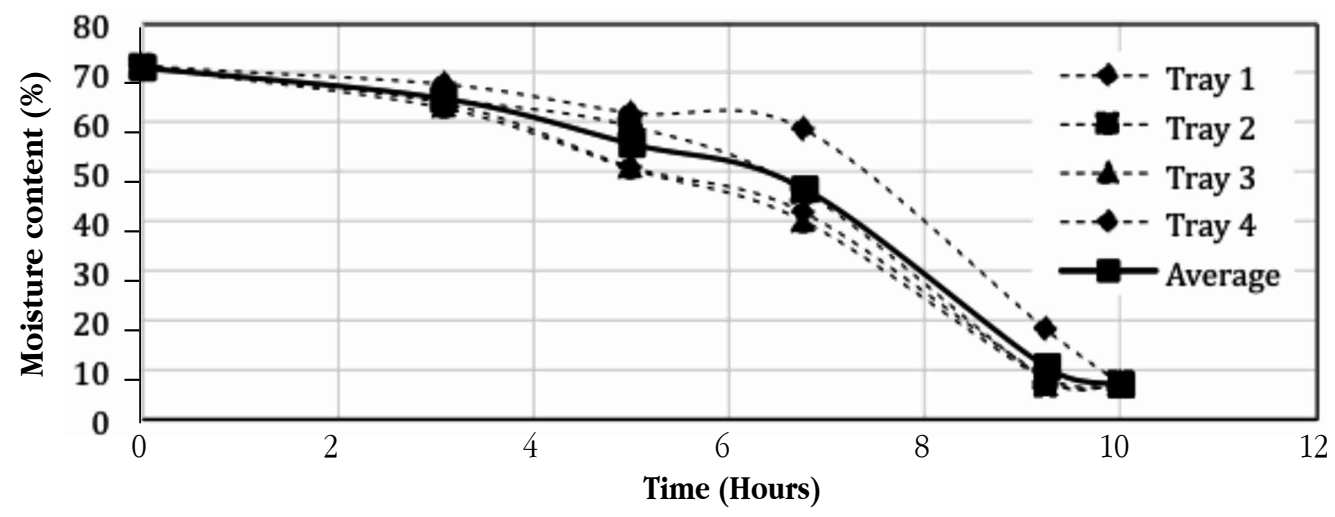

Figure 5 Drying profile of chili on biomass fueled dryer 


\section{Drying time}

The drying curve of Chili in this system was shown above in Fig 6. It was noted that the required moisture content of chilli was reached in the hybrid operation within 29 hours, while it required 50 hours (5days) for open sun drying (Tanit, 1999).

Table 5 Fuel consumption, air flow rate and efficiency of hybrid solar-biomass dryer

\begin{tabular}{|c|c|c|c|}
\hline & Case A & Case B & Case $\mathrm{C}$ \\
\hline Fuel used (kg) & 4 & 4 & 3 \\
\hline Time elapsed (min) & 95 & 100 & 107 \\
\hline Fuel consumption rate (kg/hr.) & 2.53 & 2.18 & 1.68 \\
\hline Air flow rate* $\left(\mathrm{m}^{3} / \mathrm{hr}\right.$.) & $117 / 83 / 63$ & $117 / 85 / 57$ & $66 / 47 / 34$ \\
\hline $\begin{array}{l}\text { Biomass energy supplied to the } \\
\text { system }(\mathrm{kW})\end{array}$ & 11.83 & 10.02 & 7.87 \\
\hline $\begin{array}{l}\text { Solar energy supplied to the } \\
\text { system (kW) }\end{array}$ & 1.16 & 1.75 & 2.03 \\
\hline System efficiency (\%) & 9.62 & 7.25 & 5.21 \\
\hline
\end{tabular}

\section{Product quality}

The Chillies dried in the solar-biomass fueled hybrid dryer had the same color as that dried in the sun. But the poduct dried in the sun is free from dust and protected from insects, birds and other contamination.

Table 6 Drying efficiency of hybrid solar-biomass dryer

\begin{tabular}{|c|c|c|c|}
\hline & Day 1 & Day 2 & Overall \\
\hline Initial weight of chili (kg) & 16.0 & 8.19 & 16 \\
\hline Final weigh of chili (kg) & 8.19 & 4.66 & 4.66 \\
\hline Water evaporated (kg) & 7.81 & 3.53 & 11.34 \\
\hline Energy needed to evaporate $(\mathrm{KJ})$ & 19525 & 8825 & 28350 \\
\hline Fuel used (kg) & 18.0 & 17.0 & 35 \\
\hline Time elapsed (min) & 615 & 575 & 1,190 \\
\hline Fuel consumption rate (kg/hr.) & 1.76 & 1.77 & 1.76 \\
\hline Air flow rate $*\left(\mathrm{~m}^{3} / \mathrm{hr}\right)$ & $107 / 81 / 57$ & $89 / 76 / 60$ & 78.5 \\
\hline $\begin{array}{l}\text { Biomass energy supplied to the } \\
\text { system(MJ) }\end{array}$ & 303.12 & 286.28 & 589.40 \\
\hline $\begin{array}{l}\text { Solar energy supplied to the } \\
\text { system (MJ) }\end{array}$ & 35.10 & 36.64 & 71.74 \\
\hline 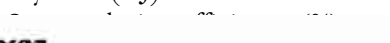 & --- & & 4.29 \\
\hline
\end{tabular}

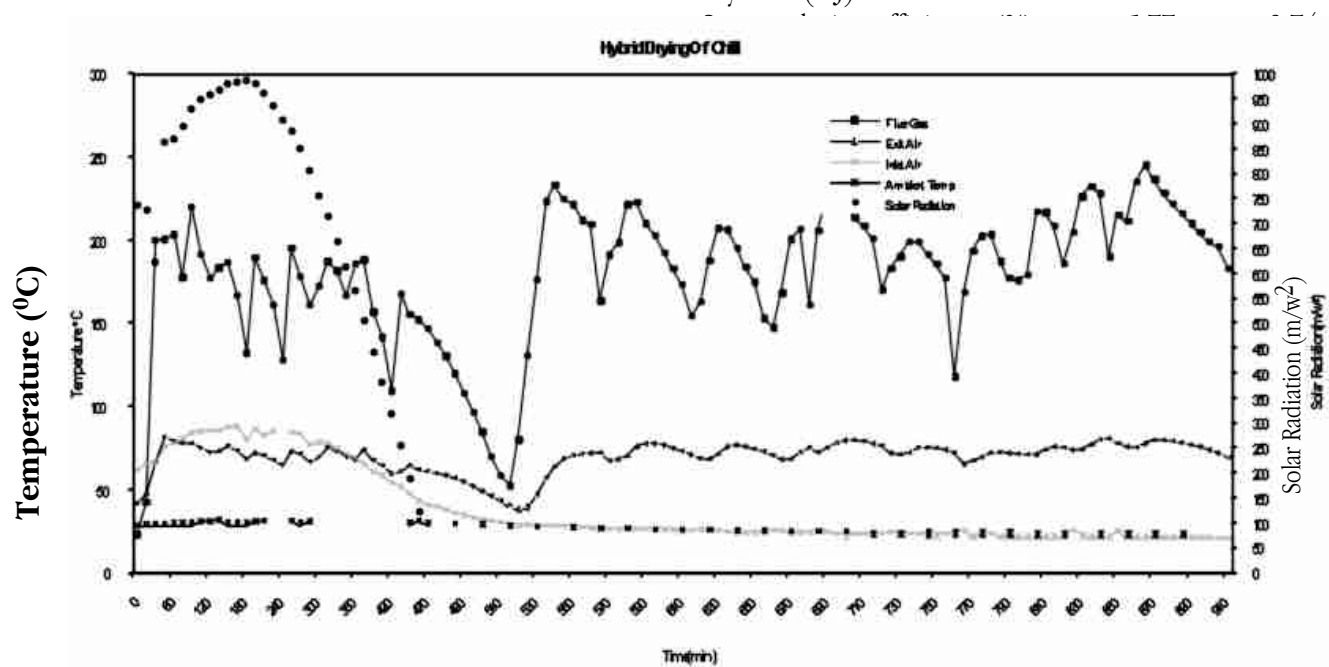

Time (Minutes)

Figure 6 Temperature profiles at various points of the hybrid operation during Chilli Drying

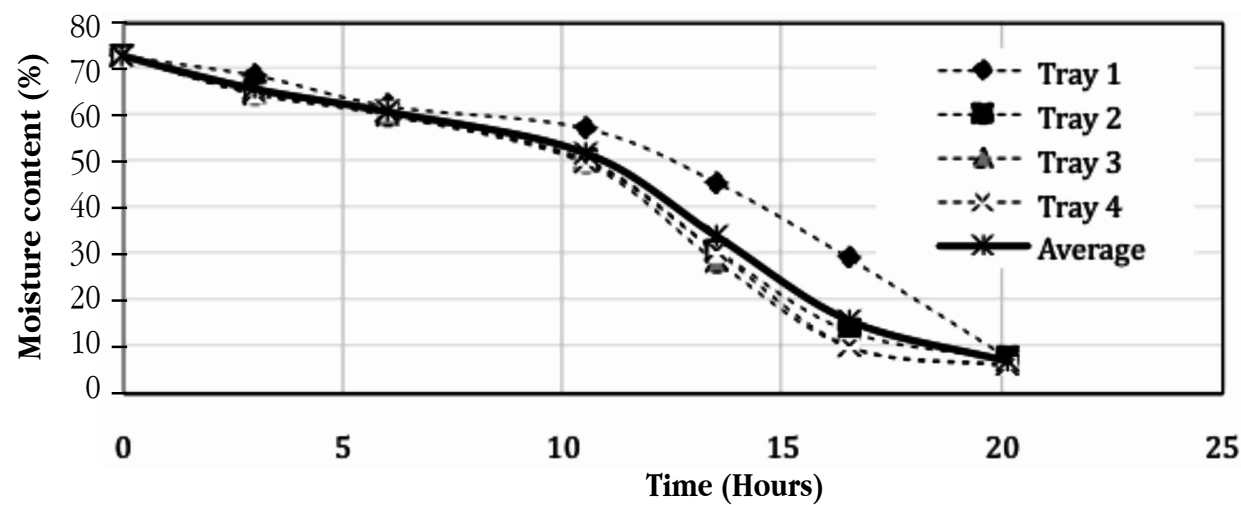

Figure 7 Drying profile of chili in hybrid solar-biomass fueled dryer 


\section{Conclusion}

The following conclusions were drawn based on the testing and evaluation of the dryer designed and developed in the study.

- A dryer consisting of an automatically controlled gasifier stove, a cross- flow heat exchanger, a dryer located above the heat exchanger and a solar flat plate collector has been designed, fabricated and tested

- Thermal energy for drying was provided by the gasifier stove alone or in combination with the solar collector.

- The final products were dried by hybrid biomass/ solar dryer were almost the same characteristics as the products which were dried in the biomass- fueled dryer.

- Final products were dried by biomass alone and hybrid solar biomass dryer were of good quality safe, hygienic with compared to products dried by open sun dryer.

- Solar/ biomass hybrid operation of the dryer showed that the temperature profiles of the drying air, drying time and quality of the products were not different compared to the operation in shade. However, operating on the hybrid mode the fuel consumed in the biomass stove can be saved about 15\% over the operation with biomass fuel alone.

\section{Acknowledgements}

The authors wish to express their sincere thanks to the Executive Director of RECAST and authorities of Tribhuvan University for providing facilities to conduct this study at RECAST premises.

\section{References}

Ahuja, D. R. Joshi, V, Smith, K. R., \& Venkataraman, C. (1987) Thermal Performance Emission Characteristic of Unvented Biomass Burning Cook stove: A Proposed Standard Method of Evaluation, Biomass, 12 issue 4, 247-270.

Asper, G.W., \& Shiun, L. (1975). Commercial Fruit Processing. The AVI Publishing Company, INC.

Bala B.K. (1997). Solar Drying of Fruits, Vegetables, Spices, Medical Plants and Fist: Developments and Potentials, International Solar Food Processing Conference, Dhaka, Bangladesh.

Gnanaranjan, N.P. (1997). A Study on Solar Tunnel Dryers for Food products AIT Thesis No. ET -97-31, Asian Institute of Technology, Bangkok.

Mahandari, C.P. (1997). A Study on Biomass-fuelled Stoves. AIT Thesis No. ET_97_28, Asian Institute of Technology, Thailand.

Mastekbayera, G.A. (1998). Performance enhancement of AIT Solar Tunnel Dryer. AIT Thesis No. 98-1, Asian Institute of Technology, Thailand.

Shrestha, K.R. (2000). Design and Testing of a Hybrid Solar/Biomass Energy Powered Drying System, A Report. Renewable Energy Technology in Asia (RETs in Asia) AIT, Thailand.

Tanit,R. (1999). A Study on Biomass Fuelled Drying Technology. AIT Thesis No ET-99-36, Asian Institute of Technology, Bangkok, Thailand. 


\section{Annex}

Annex I Moisture content of banana during the experiments on bio-mass fueled dryer (in shade)

\begin{tabular}{ccccccc}
\hline \multicolumn{2}{c}{ Drying Time } & \multicolumn{5}{c}{ Moisture content (\% on wet basis) } \\
\hline Min. & Hours & Tray 1 & Tray 2 & Tray 3 & Tray 4 & Average \\
\hline 0.00 & 0.00 & 67.37 & 67.37 & 67.37 & 67.37 & 67.37 \\
170.0 & 2.83 & 62.72 & 61.21 & 58.48 & 54.15 & 59.14 \\
366.00 & 6.10 & 54.91 & 52.87 & 51.94 & 45.42 & 51.29 \\
56.00 & 9.35 & 45.13 & 41.57 & 37.70 & 35.98 & 40.10 \\
741.00 & 12.35 & 33.09 & 27.78 & 26.39 & 25.51 & 28.19 \\
903.00 & 15.05 & 29.73 & 25.75 & 25.33 & 24.36 & 26.29 \\
1087.00 & 18.12 & 25.88 & 23.92 & 23.54 & 22.72 & 24.02 \\
\hline
\end{tabular}

Annex II Moisture content of chili during the experiments on bio-mass fueled dryer (in shade)

\begin{tabular}{ccccccc}
\hline \multicolumn{2}{c}{ Drying Time } & \multicolumn{5}{c}{ Moisture content (\% on wet basis) } \\
\hline Min. & Hours & Tray 1 & Tray 2 & Tray 3 & Tray 4 & Average \\
\hline 0.00 & 0.00 & 71.23 & 71.23 & 71.23 & 71.23 & 71.23 \\
185.00 & 3.08 & 67.89 & 64.85 & 63.07 & 64.03 & 64.96 \\
300.00 & 5.00 & 62.09 & 59.32 & 50.74 & 51.01 & 55.79 \\
406.00 & 6.77 & 58.64 & 46.09 & 40.10 & 41.77 & 46.65 \\
555.00 & 9.25 & 17.93 & 7.76 & 8.00 & 8.36 & 10.51 \\
& & 7.09 & 7.08 & 7.05 & 7.05 & 7.07 \\
\hline
\end{tabular}

Annex III Moisture content of chili during the experiments on the Hybrid operation

\begin{tabular}{ccccccc}
\hline \multicolumn{2}{c}{ Drying Time } & \multicolumn{5}{c}{ Moisture content (\% on wet basis) } \\
\hline Min. & Hours & Tray 1 & Tray 2 & Tray 3 & Tray 4 & Average \\
\hline 0.00 & 0.00 & 72.58 & 72.58 & 72.58 & 72.58 & 72.58 \\
180.00 & 3.00 & 68.69 & 64.89 & 64.74 & 64.86 & 65.80 \\
360.00 & 6.00 & 62.13 & 60.32 & 60.21 & 60.97 & 60.91 \\
630.00 & 10.50 & 57.33 & 50.64 & 49.81 & 50.18 & 51.99 \\
810.00 & 13.50 & 45.59 & 31.02 & 28.57 & 30.62 & 33.95 \\
990.00 & 16.50 & 29.31 & 13.78 & 10.32 & 10.30 & 15.93 \\
1206.00 & 20.10 & 7.96 & 7.83 & 6.53 & 6.19 & 7.13 \\
\hline
\end{tabular}

